\title{
INOVASI EKOWISATA DIGITAL SAAT PANDEMI COVID-19 STUDI KASUS: VIRTUAL EXPERIENCE OLEH SEBUMI.ID
}

\author{
Ferry Dwi Winata $^{1}$, Dyah Mutiarin ${ }^{2}$ \\ ${ }^{1}$ Magister Kajian Pariwisata Universitas Gadjah Mada \\ Email:Ferry.d.w@mail.ugm.ac.id \\ ${ }^{2}$ Magister Ilmu Pemerintahan Universitas Muhammadiyah Yogyakarta \\ Email:dyahmutiarin@umy.ac.id
}

Masuk : 13-01-2021, revisi: 26-04-2021, diterima untuk diterbitkan : 30-04-2021

\begin{abstract}
The COVID-19 pandemic has put great pressure on the tourism industry, such as a decrease in the arrival of domestic and foreign tourists, a decrease in the tourism business, and its derivatives. The dependence of tourists on technology and information has recently proven to be quite significant, especially in the covid-19 pandemic situation. Virtual Tour has recently been considered as an alternative but cannot replace the experience gained from direct tourism activities. The study used a systematic review analysis technique by taking data sources through the Scopus.com website page, by having a data search limit in the form of keywords such as: Virtual Tourism; Ecotourism; COVID19, and the limitations of the research carried out are 2000-2020. Based on the search results on Scopus, with the keywords Tourism and Pandemic, there are 124 studies in question and are divided into three clusters, namely the Tourism industry, Country, and Loss clients. This study uses a literature review method by collecting data from Scopus. Sebumi.id as the subject of this research shows that virtual tours have advantages, namely the messages and meanings conveyed are more channeled to tourists. From the observation and directly experiencing the Virtual Experience package from Sebumi.id, it was found that Sebumi Virtual Experiences is audio, visual with 360 and VR materials specially made to provide environmentally friendly travel experiences and sustainable activities from home.
\end{abstract}

Keywords: tourism, COVID-19 pandemic, virtual tourism

\begin{abstract}
ABSTRAK
Pandemi COVID-19 telah memberikan tekanan besar pada industri pariwisata, seperti penurunan kedatangan wisatawan domestik dan mancanegara, penurunan bisnis pariwisata, dan turunannya Ketergantungan wisatawan terhadap teknologi dan informasi belakangan ini terbukti cukup signifikan terutama pada situasi pandemi covid-19. Virtual Tour beberapa waktu belakangan ini dianggap sebagai alternatif namun tidak dapat menggantikan pengalaman yang di dapat dari kegiatan wisata secara langsung. Penelitian menggunakan Teknik analisis sistematika review dengan mengambil sumber data melalui laman website Scopus.com, dengan memiliki limit pencarian data berupa kata kunci seperti: Virtual Tourism; Ekowisata; COVID-19, dan Batasan penelitian yang dilakukan adalah tahun 20002020. Berdasarkan hasil pencarian di Scopus, dengan kata kunci Tourism dan Pandemic, terdapat 124 penelitian yang bersangkutan dan terbagi dari tiga cluster, yaitu cluster Tourism industry, Country, dan Loss. Penelitian ini menggunakan metode literature review dengan mengumpulkan data dari scopus. Sebumi.id sebagai subjek penelitian kali ini menunjukkan bahwa virtual tour memiliki kelebihan yaitu pesan dan makna yang disampaikan lebih tersalurkan kepada wisatawan. Dari hasil pengamatan dan merasakan langsung paket Virtual Experience dari Sebumi.id, didapatkan bahwa Sebumi Virtual Experiences adalah audio, visual dengan material 360 dan VR yang dibuat khusus untuk memberikan pengalaman perjalanan ramah lingkungan dan aktivitas berkelanjutan dari rumah.
\end{abstract}

Kata Kunci: pariwisata, pandemi covid-19, virtual tourism

\section{PENDAHULUAN}

Perkembangan industri 4.0 di era globalisasi saat ini membawa perubahan yang signifikan terhadap pariwisata. Berbagai aktivitas yang semula dilakukan dengan cara manual seperti pemesanan tiket transportasi, pemesanan akomodasi hingga paket wisata, kini beralih menjadi lebih mudah dan sederhana melalui berbagai media digital dan teknologi. Hal ini sangat mempermudah bagi seseorang atau kelompok untuk memenuhi kebutuhannya dalam kegiatan pariwisata. Tren baru ini memunculkan berbagai inovasi yang dilakukan oleh pelaku-pelaku pariwisata untuk dapat bersaing satu sama lain. 
Banyak organisasi pemasaran destinasi pariwisata telah mengembangkan Situs Web dengan berbagai tingkat interaktivitas. Berbagai laman website interaktif memberikan kesempatan yang baik bagi banyak pemasok yang terlibat dalam tujuan wisata untuk secara unik menyusun komponen spesifik dari tawaran destinasi yang dicari oleh pengunjung perorangan (Palmer \& McCole, 2000). Berbagai tekanan pada industri pariwisata sangat dengan adanya angka penurunan yang besar dari kedatangan wisatawan yang berasal dari mancanegara dengan meningkatnya angka pembatalan besar-besaran dan penurunan pemesanan pada sektor pariwisata. Penurunan juga terjadi karena adanya pengaruh perlambatan perjalanan domestik, terutama karena keengganan masyarakat Indonesia untuk melakukan perjalanan di masa maraknya wabah COVID19 (Sugihamretha, 2020). Segala kegiatan yang semula dilakukan secara langsung (secara fisik) untuk sementara tidak dapat dilakukan, termasuk kegiatan berwisata karena beresiko terjadinya penyebaran virus. Di Indonesia sendiri sampai saat ini pemerintah masih menetapkan kebijakan untuk menutup berbagai destinasi wisata sebagai bentuk tanggung jawab untuk meminimalisir penyebaran virus kepada masyarakat. Hal ini direspon oleh biro perjalanan dengan membuat paket virtual tour Sebagai alternatif kepada masyarakat untuk mengobati kejenuhan akibat tidak bisa melakukan perjalanan wisata.

Virtual Tour sebagai alternatif tentunya tidak dapat menggantikan pengalaman yang didapat dari kegiatan wisata secara langsung. Meskipun demikian, antusias orang-orang terhadap virtual tour ini cukup baik. Kemudian dengan harga paket yang sangat terjangkau dan menawarkan pengalaman yang baru menjadi daya tarik tersendiri (Wuri, 2020). Virtual Tour dikemas dengan berbagai inovasi yang menarik agar virtual tourist dapat mendapatkan pengalaman yang lebih. Merespon hal tersebut, Sebumi.id sebagai salah satu Travel Agent yang berfokus pada ekowisata berinovasi dengan menciptakan produk-produk Virtual Experience dengan konsep Ekowisata dan Adventure. (Sebumi, 2020/). Menjadi hal yang menarik bagi penulis untuk mengkaji lebih dalam terkait bagaimana Virtual Experience oleh Sebumi.id sebagai sektor ekowisata digital pandemi Covid-19.

\section{METODE PENELITIAN}

Penelitian ini menggunakan metode studi literatur berdasarkan artikel-artikel yang berkaitan dengan topik Virtual Tour dan Pandemi Covid-19. Daniel dan Warsiah (2007:80) mengungkapkan bahwa "Studi literatur adalah teknik penelitian yang dilakukan oleh peneliti dengan mengumpulkan sejumlah buku, majalah, leaflet yang berkaitan dengan masalah dan tujuan penelitian. Penelitian menggunakan Teknik analisis sistematika review dengan mengambil sumber data melalui laman website Scopus.com, dengan memiliki limit pencarian data berupa kata kunci seperti: Virtual Tourism; Ekowisata; COVID-19, dan Batasan penelitian yang dilakukan adalah tahun 2000-2020. Berdasarkan hasil pencarian di Scopus, dengan kata kunci Tourism dan Pandemic, terdapat 124 penelitian yang bersangkutan dan terbagi dari tiga cluster, yaitu cluster Tourism industry, Country, dan Loss.

Penganalisisan sumber data menggunakan VOSviewer. VOSviewer adalah perangkat lunak untuk membuat peta berdasarkan data jaringan dan untuk memvisualisasikan dan menjelajahi peta ini. Fungsionalitas VOSviewer dapat diringkas sebagai Membuat peta berdasarkan data jaringan. Peta dapat dibuat berdasarkan jaringan yang sudah tersedia, tetapi juga memungkinkan untuk membangun jaringan terlebih dahulu, dan Memvisualisasikan dan menjelajahi peta. VOSviewer menyediakan tiga visualisasi sebuah peta: Visualisasi jaringan, visualisasi overlay, dan visualisasi kepadatan (Van Eck, \& Waltman, 2013). 


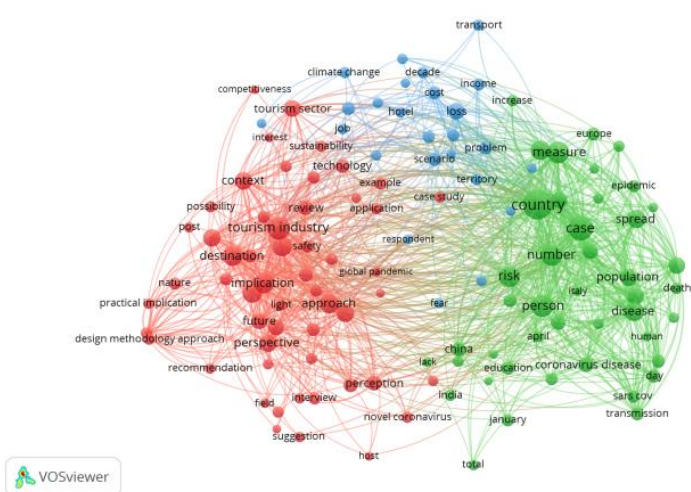

Gambar 1. Analisis VOSviewer Berdasarkan Topik Artikel

Dari gambar tersebut dengan jumlah penelitian yang masih dibawah 200, menunjukkan perlunya banyak penelitian yang mengkaji terkait dampak pandemi covid-19 terhadap pelaku pariwisata.

\section{HASIL DAN PEMBAHASAN}

Masalah COVID-19 yang muncul di seluruh dunia telah dinyatakan oleh Organisasi Kesehatan Dunia (WHO) sebagai pandemi global. Munculnya pandemi COVID-19 mempengaruhi beberapa lini sektor kehidupan, seperti sistem pemerintahan yang juga mengalami kesulitan dalam mengambil tindakan kesehatan yang diperlukan (Teter, 2020). Lambatnya antisipasi pandemi COVID-19 disebabkan karena kurangnya dana, benturan kepentingan, perputaran tenaga kesehatan, dan bidang mana yang harus diprioritaskan (Iqbal, 2020). Dalam kondisi dunia yang normal, pemerintah lebih cenderung merespon dan berkonsentrasi pada urusan politik, oleh karena itu dengan adanya pandemi COVID-19 sepertinya belum semuanya siap untuk mengendalikan kondisi pandemi tersebut (Wang \& Qian, 2020).

Kehadiran COVID-19 di dunia pada akhir tahun 2019 hingga saat ini (Juli 2020) telah merugikan kehidupan manusia dan sangat mempengaruhi sektor penting lainnya (Cheer, 2020). Sektor yang paling berpengaruh terhadap pandemi COVID-19 adalah sektor pariwisata, di Indonesia pandemi COVID-19 berdampak sangat signifikan terhadap pariwisata Indonesia (Sugihamretha, 2020). Pandemi COVID-19 telah memberikan tekanan besar pada industri pariwisata, seperti penurunan kedatangan wisatawan domestik dan mancanegara, penurunan bisnis pariwisata, dan turunannya (Chen, Huang, \& Li, 2020). Kekuatan COVID-19 dalam menghambat rantai pasokan global, terutama aktivitas dari industri jasa / perjalanan, telah mengalami redundansi, penutupan, dan cuti (Curley et al., 2020).

Industri pariwisata yang merupakan sektor unggulan pemerintahan saat ini sedang menghadapi penurunan yang cukup besar akibat pandemi COVID-19. Adanya pandemi COVID-19 di Indonesia berdampak pada aktivitas pariwisata yang terhenti sama sekali. Akibatnya adalah terganggunya supply chain dan demand secara global, tekanan terhadap keberlangsungan industri pariwisata sangat terlihat dengan turunnya kedatangan wisatawan yang cukup besar, dan berlanjutnya pandemi ini berdampak sangat buruk bagi dunia usaha pariwisata. (UNWTO, 2020). Perekonomian yang diproyeksikan tumbuh lebih dari nol persen tersebut disebabkan oleh penurunan aktivitas sektor riil, khususnya sektor jasa, pariwisata, dan penerbangan. Sektor-sektor ini, sejalan dengan analisis McKinsey, berada di bawah tekanan terkuat akibat penyebaran COVID-19. Oleh karena itu, sangat penting untuk mengkaji krisis pariwisata akibat pandemi COVID-19. Dalam tulisan ini, peneliti mencoba menjelaskan keberlanjutan pariwisata Indonesia di Era Normal Baru, dampak yang dihadapi industri pariwisata pasca pandemi COVID-19, dan 
memaparkan tanggapan pemerintah terhadap industri pariwisata di era normal baru Pandemi covid-19.

Dari hasil pengamatan dan merasakan langsung paket Virtual Experience dari Sebumi.id, didapatkan bahwa Sebumi Virtual Experiences adalah audio, visual dengan material 360 dan VR yang dibuat khusus untuk memberikan pengalaman perjalanan ramah lingkungan dan aktivitas berkelanjutan dari rumah. Ini adalah cara untuk tetap terhubung dengan alam dan aktivitas luar ruangan saat tinggal di rumah. Disediakan acara grup dan acara khusus berdasarkan kebutuhan wisatawan untuk tetap terlibat dengan tim dan kolega di ruang virtual. Dengan berpartisipasi dalam hal ini, wisatawan juga akan membantu penyedia pariwisata lokal dan UKM yang bermitra dengan Sebumi dengan menciptakan platform mata pencaharian alternatif bagi mereka selama pandemi. Jelajah pengalaman virtual dengan Sebumi memiliki beberapa pilihan sesuai dengan minat wisatawan.

Untuk wisatawan yang memiliki minat dengan kegiatan mendaki, paket Virtual Experience dengan tema Zero Waste Journey to The Highest Peak of Java dan The Mightiest Rinjani : Rise and Fall, sangat cocok untuk dinikmati. Kemudian Forest Healing Journey To The Land of Orangutan bagi pecinta alam dan peminat eksplor hutan dan rawa-rawa. Bagi peminat aktivitas snorkeling, paket Virtual Conserving West Bali Coastal And Marine With Local Communities sangat direkomendasikan. Terakhir bagi wisatawan yang berminat dengan kegiatan ekowisata untuk mengenal lebih dekat kehidupan masyarakat di pedesaan, Balinese Healing Power Of Nature menjadi pilihan yang dapat diambil. Hal spesial dari wisata virtual dengan Sebumi.id adalah kita diajak untuk menjaga kelestariaan alam dan menyejahterakan masyarakat lokal yang kehidupannya bergantung dengan alam. Hal ini direspon sangat positif bagi wisatawan dan dapat menjadi roda pemutar akan sadar lingkungan kepada masyarakat saat berwisata setelah pandemi berakhir.

\section{KESIMPULAN DAN SARAN}

Pandemi covid-19 mengharuskan kegIatan wisata dihentikan untuk sementara. Masalah tersebut tentunya berdampak cukup signifikan kepada pelaku pariwisata yang akhirnya mengharuskan mereka untuk berinovasi sebaik mungkin untuk dapat terus bertahan. Sebumi.id sebagai penyedia jasa ekowisata menyikapi hal tersebut dengan menciptakan sebuah Virtual Experience, yaitu paket wisata virtual yang dikemas tidak hanya menunjukkan gambar dan video namun juga meningkatkan pesan dan makna dari perjalanan virtual tersebut.

Tidak dapat dipungkiri bahwa wisata virtual tidak dapat mengganti nilai pengalaman berwisata secara langsung, namun di sisi lain virtual tour dapat menjadi solusi untuk membawa pola pikir masyarakat untuk lebih siap dan lebih baik menjadi wisatawan yang juga ikut serta dalam menjaga kelestarian lingkungan. Hal ini yang seharusnya ditingkatkan oleh pelaku pariwisata lainnya dan bukan mementingkan tentang keuntungan bisnis saja.

\section{REFERENSI}

Annetta, L. A., Folta, E., \& Klesath, M. (2010). V-Learning: Distance education in the $21^{\text {st }}$ century through $3 D$ virtual learning environments. Springer Science \& Business Media.

Blake, A., Sinclair, M. T., \& Soria, J. A. C. (2006). Tourism productivity: Evidence from the
United
Kingdom. Annals
of Tourism
Research, 33(4),
1099-1120. https://doi.org/10.1016/j.annals.2006.06.001 
Chen, H., Huang, X., \& Li, Z. (2020). A content analysis of Chinese news coverage on COVID19 and tourism. Current Issues in Tourism, 1-8. https://doi.org/10.1080/13683500.2020.1763269

Chew Ging, L. (2008). Tourism and economics growth: The case of Singapore. Regional and Sectoral Studies, 8(1), 89-98

Curley, A., Dichter, A., Krishnan, V., Riedel, R., \& S, S. (2020, April 22). Corona virus: Airlines brace for severe turbulance. McKinsey \& Company. Diambil dari https://www.mckinsey.com/industries/travel-logistics-and-transport-infrastructure/ourinsights/coronavirus-airlines-brace-for-severe-turbulence\#

Fahzura, N. (2021). Dampak pandemi covid-19 terhadap pariwisata halal di kota Banda Aceh. Etd Unsyiah.

Hjalager, A. M. (2010). A review of innovation research in tourism. Tourism Management, 31(1), 1-12. https://doi.org/10.1016/j.tourman.2009.08.012

Cho, Y. H., Wang, Y., \& Fesenmaier, D. R. (2002). Searching for experiences: The web-based virtual tour in tourism marketing. Journal of Travel \& Tourism Marketing, 12(4), 1-17. https://doi.org/10.1300/J073v12n04_01

Iqbal, M. M. (2020). The Effect of Regional Climatic Condition on the Spread of Covid-19 at Global Scale. Science Direct: Science of The Total Environment. Diamblil dari http://www.sciencedirect.com/science/article/pii/S0048969720336214.

Palmer, A., \& McCole, P. (2000). The role of electronic commerce in creating virtual tourism destination marketing organisations. International Journal of Contemporary Hospitality Management.12(3)198-204. https://doi.org/10.1108/09596110010320760

Priyanto, A., Purnomo, E. P., Andoko, B. W., Khairina, E., \& Fadhlurrohman, M. I. (2020). The impact of covid-19 on localtourism sector and income. MIMBAR: Jurnal Sosial dan Pembangunan, 36(2), 383-390.

Sugihamretha, I. D. G. (2020). Respon kebijakan: Mitigasi dampak wabah Covid-19 pada sektor pariwisata. Jurnal Perencanaan Pembangunan: The Indonesian Journal of Development Planning, 4(2), 191-206. https://doi.org/10.36574/jpp.v4i2.113

Sebumi/ (2020, Desember). Vitual experiences. Sebumi.id Diakses dari http://sebumi.id/virtualexperiences

Spanou, S., Tsegenidi, K., \& Georgiadis, T. (2012). Perception of visitors' environmental impacts of ecotourism: A case study in the Valley of Butterflies Protected area, Rhode Island, Greece. International Jurnal for Environmental Research, 6(1).245-258.

Teter, W. (2020). Fostering problem driven collaboration in a development context. Asia Pacific Journal of Pubilic Administration, 42(2), 89-110. https://doi.org/https://doi.org/10.1080/23276665.2020.1753222.

UNWTO. (2017). Sustainable development of tourism. UNWTO. Diambil dari https://www.unwto.org/sustainable-

development\#: :text=\%22Tourism\%20that\%20takes\%20full\%20account,the $\% 20$ environ ment $\% 20$ and $\% 20$ host $\% 20$ communities $\% 22$

UNWTO. (2020). Impact assessment of the covid-19 outbreak on international tourism. UNWTO. Diambil dari https://www.unwto.org/impact-assessment-of-the-covid-19-outbreak-oninternational-tourism

Van Eck, N. J., \& Waltman, L. (2013). VOSviewer manual. Leiden: Univeristeit Leiden, 1(1),153.

Wang, Y., \& Qian, D. (2020). Modifiable areal unit problem and environmental factors of covid19 outbreak. Science Direct: Science of The Total Environment. Diambil dari http://www.sciencedirect.com/science/article/pii/S004896972033504X 
Wachyuni, S. S., \& Kusumaningrum, D. A. (2020). The effect of COVID-19 pandemic: How are the future tourist behavior? Journal of Education, Society and Behavioural Science, 33 (4), 67-76.

Wuri. (2020, November). Virtual tour, pengalaman baru wisata di tanah air selama pandemi covid19. Merdeka. Diakses dari https://www.merdeka.com/gaya/virtual-tour-pengalaman-baruwisata-di-tanah-air-selama-pandemi-covid-19.html 